3-1983

\title{
Demography as social science and policy science
}

\author{
Dennis Hodgson \\ Fairfield University, hodgson@fairfield.edu
}

Follow this and additional works at: https://digitalcommons.fairfield.edu/sociologyandanthropology-

facultypubs

Archived with permission from the copyright holder.

Copyright 1983 Wiley and Population Council.

Link to the journal homepage: (http://wileyonlinelibrary.com/journal/padr)

\section{Peer Reviewed}

\section{Repository Citation}

Hodgson, Dennis, "Demography as social science and policy science" (1983). Sociology \& Anthropology Faculty Publications. 30.

https://digitalcommons.fairfield.edu/sociologyandanthropology-facultypubs/30

\section{Published Citation}

Hodgson, Dennis. "Demography as social science and policy science." Population and Development Review 9 , no. 1 (March 1983), pp. 1-34.

This item has been accepted for inclusion in DigitalCommons@Fairfield by an authorized administrator of DigitalCommons@Fairfield. It is brought to you by DigitalCommons@Fairfield with permission from the rightsholder(s) and is protected by copyright and/or related rights. You are free to use this item in any way that is permitted by the copyright and related rights legislation that applies to your use. For other uses, you need to obtain permission from the rights-holder(s) directly, unless additional rights are indicated by a Creative Commons license in the record and/or on the work itself. For more information, please contact digitalcommons@fairfield.edu. 


\section{Demography as Social Science and Policy Science}

\section{Dennis Hodgson}

Demography as an activity has historically contained elements both of a social science and a policy science. From Malthus's day to the present, the study of population dynamics has attracted those wishing to understand and those wishing to influence. These two activities are quite different in nature. The demographer as social scientist seeks knowledge about conditions. His stance requires no commitment to change. He is interested in "what is" and strives to apprehend reality. The demographer as policy scientist seeks to alter current conditions in a specific direction. His stance is necessarily one committed to change. He is interested in "what can be" and strives to produce a desired state.

Historically demography has passed through periods when one or the other of these motivating forces predominated among students of population. The shift in perspective from a social scientific orientation to a policy orientation and back again is a major leitmotif of the history of the field, one that has had a profound influence on the evolution of demographic thought. Since the dual nature of demography is unlikely to change, this influence can be expected to continue.

For the past 30 years global population dynamics have attracted the attention of most demographers, and the majority have assumed a policyoriented stance. The major controversy of the period-between the "developmentalists" and the "family planners" - was an expression of conflicts attendant upon pursuing policy-oriented research within an academic discipline. To offer advice on how to produce beneficial social change without doing violence to "facts" as best they are known is a difficult and stressful task. With fertility decline now becoming a pronounced trend in the developing world, there will probably be a renewed emphasis on the social scientific perspective. The goal of demographers will increasingly become to "understand" what is happening rather than to "make" something happen. What will 
this change mean for the field? How is the nature of demographic thought and research likely to change as a result of it?

It is questions like these that will be addressed here. Since the latest change in emphasis is more nascent than actual, it is difficult to examine. But insights can be gained by examining the historical record. From 1945 to 1955 a change in perspective comparable to that taking place today occurred among demographers in the United States. During the late 1940s the sharp decline in mortality and the ensuing increase in population in the world's industrially less developed areas precipitated a major reorientation in demographic research. A generation of demographers had spent their energies on producing a systematic understanding of past and present population trends in the world's industrially developed societies-the theory of the demographic transition. When they applied this "understanding" to analysis of developing world population trends, grave difficulties were foreseen. There was a cry for "social engineering." And this generation of demographers underwent a shift from a strictly social scientific perspective to one of policy orientation.

How was demographic thought and research in the United States affected by a policy orientation? When the goal became to influence demographic trends and not simply to understand them, what changes occurred in the assumptions demographers made, in the theory and methods they employed, and in the kind of analyses produced? This historical examination will not directly further our understanding of demographic processes. It might, however, further our understanding of the nature of the discipline of demography. It might provide insight not only about the past but also about the present and the future.

\section{The impending_crisis and the shift in focus:}

\section{an overview}

At times the demographer as social scientist reveals a reality that appears to foreshadow a "crisis." By its very nature a crisis situation is one in which the outcome is both quite meaningful for the future course of events and as yet undetermined. In the 1940 s and 1950 s, most US demographers came to consider mounting population growth in the nonindustrialized world, especially in already populous Asian societies, to be building toward a crisis. Would food and resource supplies be adequate to feed, clothe, and shelter large and dense populations that were growing larger and more dense? Would there be sufficient resources for such populations to industrialize, assuming basic needs could be met? Would the current period of population growth be halted by an increase in mortality (famine, disease, war) or by fertility decline?

A crisis situation often prompts the examiner to propose a course of action that would influence its resolution. There is a tendency, then, for crisis research to become policy research rather than to be strictly academic in nature. The rapid population growth of the nonindustrialized societies had exactly this effect on the nature of midcentury demographic research in the United States. While starvation, economic stagnation, and political instability were not rampant, the unbalanced vital rates threatened to lead to such eventualities. If 
fertility could not be reduced soon, the future course of events would, it was feared, be predetermined and catastrophe unavoidable. In this context Frank Notestein noted that "demographers can contribute more toward the statement of the difficulties than toward concrete and practical suggestions for their solution" (1950b: 90). He argued that "to answer the concrete questions on which information is needed," demography did not need more work on an "over-arching theory of change"' but rather required work "at lower levels of generality" — work capable of aiding in the "formation of policy" (1953: 27). "First of all," he said, "we need to know how to reduce birth rates in an agrarian society" (1948: 13). By the early 1950s many US demographers were devoting themselves to the search for ways to bring about fertility decline in nonindustrialized societies.

Substantial fertility decline had already occurred in the economically developed areas of the world. Ever since the onset of general fertility decline among Western European peoples in the late nineteenth century, this trend had been the focus of much demographic research. By 1945 an extensive literature existed about the nature of fertility decline. This literature, developing from an effort to understand a demographic trend already occurring, can best be characterized as social scientific. Understanding, not change, was the goal. Historical and comparative analysis of trends in the birth rate was the method. In fact, as shall be elaborated later, the theory that was developed from this half-century of research on fertility decline already contained an explanation for the high levels of fertility and population growth then found in nonindustrialized areas. This legacy of explanation, however, proved to be of little help when the goal of demographers shifted to lowering fertility.

A certain tension accompanied the adoption of the new policy-oriented perspective, because assuming a stance committed to change seemed "unscientific" to demographers who had previously engaged in predominantly social scientific research. ${ }^{1}$ The term perspective is used here in a Mannheimian sense. It stands for the qualitative elements in the structure of thought, that is, "the manner in which one views an object, what one perceives in it, and how one construes it in his thinking' (Mannheim, 1936: 272). Fertility decline certainly came to be viewed, perceived, and construed by demographers in a new way during the early 1950s. Formerly it had been a demographic trend occurring in the most economically developed areas of the world that needed to be explained. Now it had become a demographic trend that needed to be induced in the world's economically least developed areas if catastrophe were to be averted.

A full understanding of the causes and consequences of this shift in perspective requires a number of steps. First, the preexisting social scientific perspective on fertility decline will be elaborated, along with the consequences for transition theory of its application to issues of population growth in the modern nonindustrialized world. Second, the impact of this legacy of research and theory on the emergence of a policy orientation will be specified. Finally, the consequences for the development of US demographic thought that flowed from adopting a policy orientation during the 1950 s will be explicated. This 
detailed examination of the causes and consequences of a past shift in perspective will be used to speculate about what might be entailed in a current change in emphasis.

It is important to note at the outset the limitations of the analysis to follow. The change in demographic thinking in the United States from 1945 to 1955 is the central phenomenon being examined. No attempt will be made to comprehensively treat developments from that time to the present. "US demography" will be treated as a specific entity. Demographers within the United States primarily communicated among themselves. Their research, writing, and teaching were primarily directed at other Americans. They "rediscovered" many ideas that had been formulated at a much earlier time, selectively borrowed from the work of certain European counterparts, and made original contributions of their own. The process by which these ideas were elaborated and consensus developed can most efficiently be uncovered by focusing exclusively on the work of US demographers.

\section{The preexisting_perspective}

From the late nineteenth century through the mid-1940s, US students of population generally employed a strictly social scientific perspective when examining fertility decline. The essence of this perspective was that in the modern era fertility was a dependent variable. Investigators perceived birth rates as reacting to changes in social and economic conditions. "Understanding" of fertility trends was to be gained by identifying the socioeconomic forces at work and by specifying the means by which they influenced reproductive behavior. An appreciation of the strength of this perspective in 1945 can best be gained by tracing its rise to dominance.

The decline of the birth rate in societies peopled by Western Europeans during the nineteenth century had a profound effect on students of population. Population studies lost their close identification with the discipline of political economy and Malthusian theory. As the second half of the nineteenth century progressed, fewer studies were devoted to deducing the consequences flowing from consideration of "the principle of population." Less was heard of "the power of population," that Malthusian independent variable which had so greatly influenced the workings of economy, society, and polity.

More studies were devoted specifically to trying to understand the dramatic demographic trends then occurring. More social scientists from a variety of disciplines spent time grappling with demographic data, rather than Malthusian concepts. Why were couples in the most economically prosperous societies deciding to have fewer children? This question in particular aroused great interest. Investigators came to think that the answer lay in the monumental social and economic changes accompanying the Industrial Revolution. The work of students of population became the scrutiny of actual demographic trends to identify their socioeconomic determinants.

Census figures in the United States showed that the white population 
experienced a continuous decline in fertility from 1800 onward. Evidence of the social scientific perspective can be found quite early in US literature. For example, in 1843 the falling birth rate was related to such socioeconomic trends as urbanization and change in the class structure: "checks to natural multiplication, those arising from prudence or pride, will continue to operate with increased force as our cities multiply in number and increase in magnitude, and as the wealthy class enlarges" (Tucker, 1843: 103). By the late nineteenth century it was recognized that fertility decline was not confined to the United States but had also occurred in England and Wales, Scotland, Ireland, France, Belgium, Germany, Austria, Switzerland, Denmark, Norway, and the Netherlands. In 1893 John Billings offered the following quite contemporary sounding list of socioeconomic trends motivating couples to practice contraception: an increased desire for items that formerly had been luxuries but now were almost necessities; a desire to preserve or secure social standing through expenditures not related to childbearing; a desire to increase the quality of children, which meant spending more per child; women's increased desire to be independent of "possible or actual husbands"; and women's growing evaluation of housekeeping as being "a sort of domestic slavery" (1893: 476).

By 1900 certain widely known empirical relationships between fertility levels and socioeconomic factors were being studied by students of population. The three most prominent were the inverse relationships known to exist between standard of living and fertility level, social class and fertility level, and urban residence and fertility level. The standard and compatible explanations for these three relationships, which gradually evolved early in this century, together constituted the major "social scientific" explanation of Western fertility decline.

As a society's standard of living improved, its fertility level tended to decline. Central to most accounts of how industrialization induced fertility decline was an explanation of this inverse relationship. Consider the "standard of living argument" offered by Clark (1907: 330). He contended that when the level of wages rose in the nineteenth century industrializing societies, the general standard of living was increased for a time period sufficiently long for people to become accustomed to it. They redefined the quantity of goods and services necessary for a satisfactory mode of living. Thereafter, they voluntarily modified their reproductive behavior to preserve their standard of living. When wages rose again, the process was repeated. A "progressive standard of living," increasing from generation to generation, became the norm, and fertility became well controlled. Additional "standard of living arguments" were elaborated by others (Sumner, 1885: 23-24; Billings, 1893; Ely, 1893: 180-185; Giddings, 1898: 306, 335; Carver, 1904: 169-175; Ross, 1907: 610-611; Taussig, 1911: 231; Fetter, 1915: Chs. 32-34; Willcox, 1916: 1-15; Keller, 1917: 129-139; Sumner and Keller, 1927: 46, 70-71, 76; Bowen, 1931: 172, 201-202). Two additional hypotheses relating standard of living and fertility decline can be found in a number of these works. Attempting to preserve one's social standing in a society where the general standard of living is increasing 
can produce pressure to have fewer children. Aspiring to improve one's social standing in a society where social standing is determined by wealth can also lead to reduced childbearing.

Often found in conjunction with a "standard of living argument" was a treatment of the inverse relationship between social class and fertility level. Most work along these lines was reminiscent of Dumont's "social capillarity theory" (Dumont, 1890). ${ }^{2}$ Dumont held that as an individual focuses his attention on improving his social position in a stratified society he tends to lower his fertility. Children come to be viewed as encumbrances to his ascent. In 1907 Ross observed that with the coming of modern industrial society "the barriers of caste are down, and less and less is a man's place in society fixed by his origin. In such cases prudence bids each avoid whatever will impede his ascent or imperil his social standing. To the climber children are encumbrances, and so the ambitious dread the handicap of early marriage and a large family" (1907: 610-611). Industrialization increased the division of labor and facilitated individual social mobility. By so doing, it increased the level of societal competition and induced fertility decline. Similar contentions were made by others (Walker, 1899: 42-43; Emerick, 1911; Fetter, 1915: 415-422; Thompson, 1930: 127). ${ }^{3}$

Urban birth rates were consistently lower than rural birth rates. Urbanization was considered to negatively affect fertility by altering the economic relationship between parents and children. To the urban worker, children were more of a handicap and less of an asset than to the country farmer. They cost more to feed, house, and educate. There were fewer opportunities for them to contribute to their parents' income (Thompson, 1930: 127; Fetter, 1915: 416-422; Emerick, 1911: 71-80). Thus the movement from the countryside to the city that accompanied the Industrial Revolution was considered to have had an independent negative impact on the birth rate.

By 1930 treatments of Western fertility decline included all the above arguments (Reuter, 1923; Ross, 1927; Thompson, 1930). Study of fertility differentials and analysis of historical trends had firmly related fertility decline to the industrialization process. Once this had happened, it was only a matter of time before there developed a general theory of modern population dynamics. Mortality decline and population growth-trends that preceded fertility decline-had already been linked to the Industrial Revolution. The increase in productivity, improvements in technology, and advances in scientific knowledge that had accompanied industrialization in the West were considered to have been responsible for the decrease in mortality (Willcox, 1906: 41-70; Rossiter, 1911, 1923; Hoffman, 1914). At the turn of the century substantial population growth, the "expansion of Europe"' as Willcox labeled it in 1906, was considered the most notable worldwide demographic trend since 1750. In a number of Western societies fertility levels began approaching already low mortality levels during the 1920s. With rates of population growth declining, the development of a theory which contended that a surge and subsequent decline in population growth is associated with industrialization seemed inevitable. 


\section{The development of transition theory}

The theory of the demographic transition is basically such a theory. It was the culmination of over half a century of social scientific analysis. Called an "integrated theory of a high order" and "a 'binder' for demography's diverse and particularized findings" (Vance, 1952: 12), its formulation in the mid1940s was met with enthusiastic acceptance. Interestingly, transition theory's formulators included individuals who a decade later would adopt the policyoriented perspective toward fertility decline. As shall be seen, the nature of transition theory itself may have played an important role in their conversion.

It is important to describe in some detail the development and content of transition theory. In the mid-1940s it was considered to be the culminating theoretical revelation that clarified the nature of modern population dynamics. Transition theory as originally formulated differs from what is now specified by some as transition theory. The original formulations, and not the more contemporary variants, will be examined.

Transition theory specifies the relationship between socioeconomic change and demographic change. If the theory is simply considered to be the contention that all societies undergoing the shift from a predominantly agrarian economic structure to an industrial one will experience a shift in demographic patterns similar to that occurring in Western societies, then it is difficult to determine exactly when this theory arose. From an early date many investigators did tend to generalize in this manner. A more rigorous definition would consider transition theory to be that theory which makes two assertions about the relationship between socioeconomic change and demographic change. First, the demographic pattern of high vital rates associated with an agrarian society will gradually shift to a regime of low vital rates as that society increasingly becomes industrial. Second, this demographic shift will be accomplished by mortality declining more rapidly than fertility, thereby producing a period of population growth.

The outlines of the first assertion can be found in the works of Taussig (1911: 220-221) and Willcox (1916: 9-12). The second assertion can be found in works by Ross (1909: 36-37) and MacIver (1926: 301). In his 1929 article, "Population," Thompson placed all of the world's societies in a tripartite typology congruent with the rigorous definition of the theory: Group A countries with low and declining rates of natural increase due to rapidly declining birth rates and already low death rates; Group B countries with increasing rates of natural increase due to rapidly declining death rates and only slowly declining birth rates; and Group $\mathrm{C}$ countries with fluctuating rates of natural increase due to vital rates not subject to substantial human control. However, the term "transition theory" as well as a definitive statement of the theory was not to emerge until the mid-1940s.

Transition theory was the byproduct of work undertaken by demographers at Princeton's Office of Population Research. Under the direction of Frank W. Notestein, the Office was engaged from 1936 to 1946 in a series of demographic studies of Europe on behalf of the League of Nations. Virtually a whole generation of US demographers, a generation that was to shape much 
of contemporary demographic thought, participated in this research: Frank Notestein, Irene Taeuber, Dudley Kirk, Ansley J. Coale, Wilbert E. Moore, Frank Lorimer, Louise Kiser, Clyde V. Kiser, and Kingsley Davis. In the course of projecting future European demographic trends, the Princeton demographers explored the by then commonplace observation that the population dynamics of Eastern and Southern Europe were similar to those of Western and Northern Europe at an earlier time. ${ }^{4}$

In 1943 Notestein raised the level of generality of the transition framework from the historically descriptive to the theoretically predictive with the contention that a "vital revolution" was sweeping Europe (1943: 165). Kirk (1944: 28-35) was the first to universalize the "vital revolution" by contending that all populations could be placed on a single "continuum of demographic development." Kirk specified three stages of this continuum, which were reminiscent of Thompson's tripartite typology. By 1945 three additional elaborations of transition theory by Notestein (1945), Davis (1945), and Thompson (1944) had been published, and an entire volume of The Annals (Davis, 1945) was devoted to transition analyses of worldwide population dynamics.

There was nothing especially "revolutionary" about transition theory. Its rapid and near universal acceptance is unsurprising in that its two major assertions had long been accepted by demographers. As Notestein (1.945: 39) observed, "the essentials of the story are simple enough. The whole process of modernization in Europe and Europe overseas brought rising levels of living, new controls over disease and reduced mortality." Fertility was "less responsive" to the process of modernization but eventually it, too, began to decline. Couples in economically advanced societies reduced the number of their offspring "in response to drastic changes in the social and economic setting that radically altered the motives and aims of people with respect to family size" (1945: 40). Because mortality responded more quickly to the modernization process than fertility, a period of rapid population growth ensued. The Princeton demographers did elaborate on earlier explanations of fertility decline. ${ }^{5}$ Since studies of the demographic trends of Japan then existed (Crocker, 1931; Uyeda, 1933; Penrose, 1934, 1940; Holland, 1936; Taeuber and Beal, 1944), which indicated that it was repeating the Western sequence of demographic change, they were also able to more confidently relate fertility decline to the industrialization process.

What was novel in transition theory as specified during the 1940s, and what is little remembered today, is that all of its original formulators expanded transition theory's explanatory power beyond the industrialized world. Kirk (1944: 28-35), Notestein (1945: 50-57), Davis (1945: 5-11; 1950b: 10-14), and Thompson (1946: 251-318) included in their formulations of the theory a "colonial explanation" of the demographic trends of nonindustrialized societies. The explanation, nearly identical in each case, contended that where traditional societies experienced colonial domination, an attenuated, onesided modernization experience produced mortality decline, population growth, but no fertility decline. In promoting their colonies as sources of raw materials, mother countries consistently introduced certain socioeconomic changes: the 
rationalization and commercialization of agriculture, the maintenance of internal order, improvements in transportation and communication, and implementation of public health innovations. Mortality declined as famine and epidemics were brought under control. But because, in promoting their colonies as markets for their own industrial goods, mother countries prevented or failed to foster industrialization, fertility remained high. Thompson (1946: 313) labeled the resultant substantial population growth as "the Malthusian dilemma of all colonialism." He contended that it would help precipitate the demise of the colonial system.

The colonial explanation was in essence an elaboration of an observation made much earlier: mortality and fertility respond to different subsets of socioeconomic changes associated with the modernization process. ${ }^{6}$ This explanation paralleled the explanation of demographic trends of industrializing societies: social structural changes were seen as the causal agents affecting demographic trends in both settings. The fact that all the originators in the United States of transition theory developed a colonial explanation also indicates that by the mid-1940s the "population problem" of the postwar world was already coming into focus. Transition theorists clearly recognized that mortality decline and population growth could be, and were being, experienced by nonindustrializing societies. Although they hoped that all societies would undergo the "demographic transition," they did not argue that all "necessarily" would. The full process of "demographic evolution" (a term used by Kirk) outlined in transition theory purported to represent only the sequence of demographic change that industrializing societies would experience. Fertility decline and a regime of low vital rates were considered the demographic consequences of experiencing industrialization. They were not considered to be inevitable.

All the formulators of transition theory used the presence and extent of fertility decline as the criterion for classifying societies in the three-stage framework of the demographic transition. ${ }^{7}$ Societies with high and static fertility were in the initial stage of demographic development, "high growth potential." Evidence of fertility decline was the demographic trait that indicated that a population had progressed to the "stage of transitional growth." A low level of fertility was the demographic trait indicating movement into the final stage of demographic development, "incipient decline." One essential generalization was the basis of transition theory's three-stage framework: a society that industrializes will undergo fertility decline.

Viewed in terms of the preoccupation of US students of population for the preceding half-century, the mid-1940s was a time of great "success" and "consensus." Transition theory, by viewing all modern demographic trends as responses to that nexus of structural changes called "the modernization process," seemingly was capable of "explaining" worldwide population dynamics. This perspective viewed demographic change as a subsidiary component of the general modernization process. A decline in mortality had resulted from increased productivity in both agriculture and industry, improvements in transportation and communication systems, advances in scientific knowledge, 
and implementation of public health innovations. This decline had been monumental in industrialized societies but also evident in much of the rest of the world. Industrialization produced a rising standard of living, an increasingly complex division of labor, elimination of ascriptive class systems, a competitive social milieu, and individualism. These changes, as well as urbanization, induced couples in industrializing societies to have fewer children. In societies that had not industrialized, high fertility remained the norm.

Transition theory, a preeminent product of the social scientific perspective, considered fertility to be a dependent variable. One could "understand" fertility decline if one perceived fertility to be reacting to change in the social system. Transition theorists tended to argue that fertility was always a dependent variable, that it was possible to understand the fertility level of any society by analyzing the components of its social system. Both Davis and Notestein, for instance, observed that all societies in the premodern era had to cope with high mortality. The omnipresence of high mortality resulted in social systems structured to induce high fertility. As Notestein (1945: 39-40) argued, successful (i.e., surviving) societies were those in which "religious doctrines, moral codes, laws, education, community customs, marriage habits, and family organizations are all focused toward maintaining high fertility.' He even went on to observe that "these change only gradually and in response to the strongest stimulation."' Davis (1948: 561-562) categorized premodern societies as being "familistic societies," ones in which kinship was the primary basis of social organization. Offspring in such societies are needed to attain nearly every life goal: "The salvation of the soul, the protection of the hearth, and the assurance of affection may depend upon the presence, help, and comfort of progeny. This arrangement, this articulation of the parental status with the rest of one's statuses, is the supreme encouragement of fertility.",

The social scientific perspective, therefore, had produced an explanation of fertility decline and fertility level that emphasized how greatly reproductive behavior was determined by social structural factors. Such a vision of fertility was to produce difficulties for transition theorists when they later assumed a policy orientation. Seen from within the social scientific orientation, inducing fertility decline in predominantly agrarian societies would be a very difficult, perhaps impossible, task. Yet this same social scientific vision of fertility also played a role in convincing transition theorists of the great need to alter their perspective and attempt this difficult task.

\section{Confronting_population growth in the nonindustrialized world}

The period of self-congratulation following the formulation of transition theory proved to be quite short. The postwar "baby boom" of the United States and other highly industrialized societies raised questions about transition theory's predictive abilities for these "regions of incipient decline." Modernity apparently had so diffused throughout the populace of these societies that their demographic trends could no longer be predicted or even "understood" within 
the transition framework. Certain US demographers looked to psychosocial factors to explain fertility in industrialized societies. ${ }^{8}$

During the postwar period, however, most of the formulators of transition theory increasingly focused their attention on the demographic trends of the nonindustrialized world. In these "regions of high growth potential" mortality decline and population growth were increasing in intensity. Transition theory's explanatory and predictive powers for societies not yet fully modernized were being confirmed. Yet this confirmation produced a feeling of foreboding rather than satisfaction. For it was particularly within the context of transition theory that the demographic trends of industrially underdeveloped societies appeared ominous. Rapid population growth came to be seen as hindering the emergence of those very socioeconomic changes that, if the experience of the already modernized world were to be used as a benchmark, would induce fertility decline and the eventual cessation of population growth. The congruity of fact and theory worked to imbue the demographic situation of industrially underdeveloped societies with an aura of impending crisis.

During the first postwar decade, transition demographers became increasingly pessimistic about the prospects for economic growth outpacing population growth in nonindustrialized regions. Their mounting pessimism pushed them from a strictly social scientific stance to an explicitly policy-oriented one. This change characterized a large share of demographic research in the United States. A detailed examination of the writings of two prominent demographers whose earlier work contributed significantly to the development of transition theory and who published often during this period, Frank Notestein and Kingsley Davis, provides insight as to why the change occurred and how it affected demographic thinking.

The work of Notestein

In the mid-1940s Frank Notestein $(1943 ; 1944 ; 1945)$ was offering classic transition theory descriptions and prescriptions for "areas of heavy population pressure." The standard "colonial explanation"' was offered as the reason behind the noticeable trends of mortality decline and population growth (1943: $174 ; 1944: 147)$. Population growth was considered particularly problematic for those already densely settled areas judged to have an insufficient resource base.

It was clear to Notestein that fertility decline was needed to humanely halt this growth. Yet he argued (1944: 152) that "there is no quick demographic solution to the problems of population pressure." A direct attempt to induce couples to use contraceptives was not likely to succeed (1945: 66). "Nearly all peoples" possessed knowledge of potentially effective contraceptive practices; the prevalence of contraceptive practice was determined primarily by social structural factors. Change the social structure with "a complete and integrated program of modernization," and fertility would decline, "for it is only when rising levels of living, improved health, increasing education, and rising hope for the future give new value to the individual life that old customs break and fertility comes under control' (1945: 57). If Western nations would 
like to help solve this " population problem," they could best do so by fostering modernization efforts.

By 1948 the economic problems associated with population growth began to loom larger in Notestein's thinking. He came to see population growth itself as a major factor inhibiting successful modernization: "for a large proportion of the world it is the impact of economic and social change on population growth that presents one of the major obstacles to modernization" (1948: 9). A specter of increases in total production that only matched increases in population came to haunt Notestein's analysis. "Such 'progress' may amount to setting the stage for calamity. Much of Asia seems to be perilously close to this situation"' (1948: 12). Rather than repeating the Western demographic experience, a new end to rapid population growth was contemplated for Asia: "A sober consideration of the existing situation leads one to expect that catastrophes will in fact check rapid growth" (1948: 13). "Rapid economic development" and "giving attention in regional planning to those changes which bring pressure on the birth rate", were urgently suggested "to forestall such tragedy" (1948: 13).

In 1950 Notestein espoused the thesis that "economic development needs to be accompanied by explicit efforts to reduce fertility"' (1950b: 89). Relying upon "urban industrial development" to lower birth rates was a risky undertaking that might threaten the ultimate success of efforts to raise living standards (1950b: 98). Historical experience indicated that a trebling of the population could be expected during the transitional growth stage. Some regions, by Notestein's reckoning, were in no position to support growth of such magnitude.

In 1952 Notestein offered a comprehensive and theoretically coherent rationale for an interventionist policy. He presented a standard version of transition theory but then followed with an equally lengthy consideration of apparent exceptions to the transition model, including the birth rate declines in eighteenth century agrarian France and more recently in Bulgaria, an "almost wholly agricultural area." He concluded from this analysis that the rise of urban-industrial society "provided no mystical means for the reduction of fertility' (1953: 18). Such reduction can occur and has occurred in a variety of settings.

With regard to contemporary densely settled agrarian societies, Notestein saw " almost insuperable difficulties involved in achieving the sort of economic development required to permit reliance upon the automatic processes of socialeconomic change for the transition to low birth- and death-rates" (1953: 25). Birth rates had to be lowered to permit economic development. But how? Notestein argued that the present state of knowledge within demography and sociology was "wholly inadequate" for the task. While noting that both "theory and experience" indicated it would be difficult to directly lower birth rates of peasant societies, he contended that they did not "necessarily" rule out the possibility. But Notestein went further. He advocated "direct measures" to lower fertility: "It is within the bounds of possibility that the wise use of modern methods of communication and training to promote higher marriage 
age and the practice of birth control would bring a considerable reduction of the birth-rate even in peasant societies"' (1953: 28).

A clear shift took place in Notestein's thinking from the mid-1940s to the mid-1950s. At the beginning of this period he employed a strictly social scientific perspective to examine the population dynamics of nonindustrialized areas. Demographic variables were dependent variables, determined by social structural factors. Demographic change was a consequence of socioeconomic change. If the attenuated modernization produced by colonial domination had caused mortality decline but no fertility decline, then fertility decline could be induced by fostering comprehensive modernization.

As the decade progressed this "remedy" for rapid population growth lost its allure. Notestein came to consider population growth itself a stumbling block to economic development. For Notestein, still a transition demographer, it was axiomatic that the social structure of "still agrarian regions" had not been altered in such a way as to bring about fertility decline "naturally.", Active intervention to lower fertility was needed if there was to be economic development. Thus by the end of the decade Notestein was viewing demographic trends as independent variables, as determinants of economic trends; rapid population growth was a cause of continued underdevelopment. He now viewed fertility from a policy perspective, as a variable that had to be lowered by policy interventions to avert human suffering.

Notestein's faith in the potential effectiveness of the direct approach increased over time. In 1954 he noted that "most people, however uneducated, are far from stupid." He continued, "They may be counted upon to be interested in understanding the nature of situations that present problems in terms of their own values and to seek solutions of such problems" (1954: 166). Sequential issues of the annual "Report of the President" written during the years when Notestein held that office at the Population Council exhibit his growing confidence that such interventions as national family planning programs could bring down birth rates in nonindustrialized areas. The development of the oral contraceptive and the intrauterine device, the latter heavily funded by the Population Council, increased Notestein's confidence that the "direct approach" could succeed. ${ }^{9}$

\section{The work of Davis}

The same factors that had worked to bring about a shift in Notestein's thinking affected the thinking of a whole generation of demographers in the United States. The writings of Kingsley Davis provide a second example of this metamorphosis. By the mid-1950s Davis, a steadfast advocate of the social scientific perspective, was also contending that "the planned diffusion of fertility control in a peasant population prior to, and for the benefit of, the urbanindustrial transition" was a viable (and the most humane) policy for a country such as India to pursue (1954: 88).

Even more than Notestein, Davis came to his ideas on the interaction of socioeconomic change and demographic change through study of individual contemporary nonindustrialized societies. Because of his abiding interest in 
India, the "crowded agrarian region" par excellence, he had to face quite early the question of whether the substantial population increases in certain nonindustrialized areas might forestall (or prevent) the recurrence of the Western "urban-industrial" and "demographic" transitions. In grappling with this question, he came to consider current rates of population growth to be "dysfunctional" and to advocate policies aimed at directly lowering fertility within still agrarian societies.

Davis's first published work dealing with his Indian research-a brief review of India's recent demographic trends-appeared in 1944. This review focused on India's then-considered-substantial population growth (a 54 percent increase from 1872 to 1941), which had come about through increased mortality control. Davis, who even at this early date employed a standard transition framework in his analysis, found nothing "strange" in the recorded trends. In the transformation of an "archaic type of civilization", into a "modern type," the death rate "generally declines before the birth rate." Therefore, a period of substantial population increase was to be expected. If the transformation proceeds smoothly, he noted, "the forces of modernization finally depress the birth rate too and thus restore the balance of births and deaths" (1944: 43). However, within this context, he considered the question of whether the situation of India (and other parts of the Orient) was "peculiar in any way that will prolong or intensify the lag" between death rate decline and birth rate decline (1944: 44). To this question he tentatively offered an affirmative answer.

Davis found in India's "semi-colonial status," and in the fact that it had borrowed rather than originated "the cultural revolution," reasons to predict that fertility was not likely to be quickly brought under control. In the West the modernization process had arisen internally, population density was comparatively low, and many outlets for emigration existed when population growth occurred. Furthermore, it had been easy to establish "a monopoly over the virgin resources and expanding markets of the entire world" (1944: 44). In India certain socioeconomic changes had been imposed from without on an already densely settled, politically dominated people. The "rigid caste system", and "very otherworldly religion" were "most impropitious for modernization" (1944: 44). There were few outlets for emigration, and the markets for potential exports were already dominated by industrial nations. As a result, India had become "a satellite nation" that had "not developed a balanced economy and had consequently not achieved the internal structure that will motivate her citizens to reduce their fertility"' (1944: 48).

The "one-sided" modernization that India experienced hastened mortality decline, while exaggerating the lag of fertility decline. Under British rule railroads and highways were constructed, irrigation was expanded, and public health measures were introduced. Famines and epidemics grew less severe. But these changes conducive to mortality decline were all characterized by "their alien origin and their non-interference with daily life", the "texture of Indian life" had undergone no substantial alteration (1944: 46). Thus the 
foundation had been laid for the creation of "an unstable demographic situation."

Davis examined the three demographic means of reducing population growth: rising death rates, emigration, and the reduction of fertility. For humanitarian and political reasons, he saw little policy potential in the manipulation of the first two demographic variables. This left policies aimed at fertility reduction. These he, like Notestein, dichotomized into "indirect" and "direct" interventions. ${ }^{10}$ By indirect interventions he meant the promotion of those aspects of the modernization process that were likely to induce fertility decline: hastening industrialization, facilitating social mobility, and increasing education. Since these changes were quite monumental in nature, and in fact the desire to see such changes come about was the main reason why one wished to implement a population policy, he argued that "their feasibility is likely to be decided on other grounds than population alone" (1944: 54). Furthermore, remaining true to the transition framework, he acknowledged that the implementation of these changes would probably lead to an even more rapid increase in population for several decades, and not to a quick cessation of population growth.

With respect to the feasibility of direct intervention-taking "birth limitation directly to the people"-he also saw "little hope of early success." Even though fertility reduction might technically be more easily implemented than mortality reduction, one had to remember that India's "social system" for many centuries had been "geared to producing high fertility." While acknowledging that "there is just enough truth in this view [the direct approach] to justify some sort of birth control program," Davis contended that the "sociological barriers are so great that such a program alone would probably have no effect, and might in fact be a boomerang" (1944: 56; emphasis in original). His final policy recommendation was that, "because the industrial and demographic revolutions are apparently inseparable, a rapid and balanced modernization (with a sociologically intelligent program of fertility control integrated with it) seems the only feasible alternative in ultimately halting the detrimental rate of population growth" (1944: 57).

In general this 1944 analysis showed Davis to be working within the confines of the transition framework. At this time Davis seemed not to be particularly pessimistic about the ultimate fate of nonindustrialized regions; he expected them to eventually complete the demographic transition. He noted that in India the indexes of economic development (i.e., industrialization, urbanization, and education) had shown a more rapid increase than population (1944: 56). In his 1945 exposition of transition theory he observed that this was generally true for the nonindustrialized world (1945: 10). This led him to conclude that "the Asiatic peoples, and others as well, will acquire modern civilization in time to check their fertility and thus achieve an efficient demographic balance"' (1945: 10).

Yet this optimism did not last long. Only a year later Davis was calling "rapid and massive population growth" India's "gravest problem" (1946: 
243). Noting that economic development could not "indefinitely provide for increasing numbers," he argued that fertility reduction was the "only alternative to a calamitous rise in the death rate" (1946: 243). Over the next several years, as the unprecedented nature of current rates of population growth became clear, the possibility of mortality increase turned into a probability, and Davis's optimism soured. In two papers published in 1950 Davis considered the following question posed by rapid population growth: "Can industrialization of the underdeveloped areas be achieved in face of their population problem?" (1950a: 43). Population growth had become an independent variable in Davis's thinking and economic change a dependent one.

Davis divided the world into two parts: "the archaic agricultural nations" and "the modern industrial nations." He held that the prior emergence of industrialism within certain areas of the world and the subsequent political and economic domination these areas exercised over agricultural regions profoundly affected the agricultural regions' current "opportunities for acquiring industrialism" (1950b: 8). A "melancholy state" had been reached "in which great numbers in relation to developed resources live at extremely low levels" (1950a: 45). The current growth and "excessive density" of agricultural populations made it "very difficult for them to industrialize and thus escape their poverty" (1950a: 45). Even if some societies successfully transcended the initial stages of industrialization, they faced the prospect of substantial population increase, "since rapid population growth has been the normal accompaniment of industrial development" (1950a: 45). This growth would, itself, jeopardize their modernization efforts. Thus, the thesis of a vicious circle of poverty and population growth had entered into Davis's analysis.

How would this circle be broken? The scenario Davis outlined in "Population and change in backward areas" as the most likely sequence of events was quite stark. The circle would be broken by "strife and turmoil, which at once reduce the existing demographic glut and sweep away old institutions and vested interests" (1950a: 49). Apparently Davis considered the demographic and socioeconomic conditions of the nonindustrialized world to be so dire that the "cleansing" effect of turmoil and mortality increase was needed before improvement could be envisioned. Of course Davis did not recommend that turmoil and mortality increase be consciously stimulated as a policy measure; but he warned that "from a strictly scientific, or dispassionate, point of view" the chances of alternative resolutions to this crisis proving effective "do not appear good" (1950a: 49).

In "Population and the further spread of industrial society," his other 1950 article, Davis was more optimistic about the possibilities for fertility reduction, although still concluding that mortality increase was the more probable outcome of the current period of growth. He began his move toward an unqualified advocacy of the "direct approach" to controlling fertility by arguing that the high birth rates of traditional societies "should not be regarded as inherently unmodifiable in the early stages of industrialization" (1950b: 16-17). Since traditional cultures had already been modified by colonial domination, "perhaps they can be modified with regard to fertility as well" $(1950 \mathrm{~b}$ : 
17). He then proceeded to marshal evidence in support of his contention.

When female respondents in a rural area of India were asked how many living children a woman of 40 should have, there was a modal preference for two or three children. This, according to Davis, "suggests a desire among Indian peasants for small families" (1950b: 17). There were urban/rural and literate caste/illiterate caste fertility differentials; also, fertility among "certain highly placed groups" was declining. These findings led Davis to conclude that, for India at least, "the pattern of lower fertility thus appears to be incipient" (1950b: 17). ${ }^{11}$

Davis acknowledged that "the present mixed culture in agricultural societies will not itself spontaneously evolve a pattern of family limitation in advance of industrial change"' (1950b: 17). What might activate this incipient decline, however, was intervention in the form of an "all-out governmental campaign backed by every economic inducement, educational device, and technical assistance to diffuse contraception"' (1950b: 17). Since no such campaign had ever been attempted, Davis admitted that there was no way of determining whether, or to what extent, it might affect fertility. Yet by marshaling evidence indicating that desire for family limitation existed among peasant couples and by recommending a program that would allow couples to behave in accordance with this desire, Davis was edging toward advocacy of national family planning programs as a potentially feasible means of dealing with the nonindustrialized world's population crisis. In time this advocacy would be more clearly expressed.

Davis's analyses of the Indian situation, which appeared from 1951 through 1954, reflect this change in his thinking. In his definitive work, The Population of India and Pakistan, no mention was made of any "incipient" downward trend in Indian fertility statistics. Rather, "the melancholy conclusion" was reached that "no sharp decline in the birth rate can be expected until deliberate control by means of contraception, sterilization, abortion, etc. is inaugurated. Today there is no real evidence that such methods are being adopted by any wide sector of the population" (1951: 82). Davis pessimistically argued that "population growth has become a frankenstein" (1951: 220). In this work, however, he made several novel contentions about the practicality of the direct and indirect approaches to limiting fertility. First, although noting that certain sociological barriers would hamper attempts to stimulate peasants to practice birth control, he argued that political impediments to government sponsorship of effective birth control programs were a greater threat to the success of the direct approach than were the sociological barriers (1951: 229). Second, Davis contended that the indirect method of "changing conditions of life and thus forcing people in their private capacity to seek the means of family limitation" would be slower in effect and more difficult to execute than the direct approach (1951: 230).

In The Population of India and Pakistan, Davis concluded his treatment of population policy by juxtaposing an "ideal population policy" with a view of "probable events." Ideally, he argued, governments of such nations as India and Pakistan ought to pursue a policy that incorporates all of the humane 
methods of dealing with population growth: strategic emigration programs, "planned parenthood" programs, and centrally administered programs of rapid industrialization. "Realistically," Davis expected the industrial state to be achieved only after these societies experienced the rise of totalitarian regimes, completely planned economies, and temporary mortality increases. In this type of industrialization process calamities would occur, and, since there would be more people relative to resources, greater poverty would exist after the process had been completed. The relative loss of lives and wealth entailed in these "probable events" Davis traced directly to the present "unwillingness" of governments to implement effective family planning programs (1951: 231). The juxtaposing of these two scenarios presented a strong case for the immediate implementation of family planning programs. And, no doubt, that was Davis's intent.

In several subsequent works Davis moved farther away from the constraints of the transition framework and became an even greater advocate of direct measures to reduce fertility. In a plainly worded paper presented in 1953, "Future population trends and their significance," Davis contended that "there is no inherent reason why peasant-agrarian populations cannot adopt the customs of fertility control, in advance of and to the advantage of modern economic development"' (1953: 18). Now apparently a society that had not even begun to industrialize could hope to lower its fertility. Although past attempts to inaugurate family planning programs in "backward areas" had met with little success, these attempts had been "half-hearted," had used "middleclass birth control methods," and had not been accompanied by "propaganda and education"' (1953: 19). They had been bound to fail. If new birth control technologies could be developed and if governments would use the means at their disposal to construct effective family planning programs, Davis contended, then "the results may prove astounding to the skeptics" (1953: 19). His experience in India, he noted, had "opened my eyes to some of the possibilities." The conditions of peasant life in backward countries had markedly changed in a direction to awaken the peasant's interest in family limitation. Apparently the changes that Davis in 1944 had described in terms of "their alien origin and their non-interference with daily life"' by 1953 he considered to have actually substantially altered the "texture of life" of the peasant.

In "Social and demographic aspects of economic development in India," a paper also composed in $1953,{ }^{12}$ these changes were enumerated in some detail. Davis presented a view of how the typical Indian villager's social milieu had been altered in just the past 30 years. The villager had seen the population of his village double, the cost of land spiral, the size of holdings dwindle, the cost of purchased items quadruple, and the return from his labor dwindle (1955: 286). With better health care, more of his children were living and the size of his family was correspondingly larger than that of his parents. ${ }^{13}$ Furthermore, with changes occurring ever more frequently, he came to view education as a means of improving his children's life chances. Naturally, he desired to give them that advantage. Arguing that the peasant, though poor and illiterate, was not "stupid," Davis concluded that "he may easily connect these events with 
the increase of population" ; clearly he was "no longer living under conditions in which a high birth rate had utility" (1955: 286).

In a 1954 paper, "Fertility control and the demographic transition in India," Davis, as had Notestein, questioned the validity and utility of transition theory. He began by asking how accurate "as a description of fact" this theory had been for the Western experience. He noted that the length of the transition period from high to low vital rates had varied greatly among Western countries. He also pointed out that the magnitude and contour of the gap between mortality and fertility decline had exhibited no universal pattern. Finally, he emphasized that the West's increase in fertility since the mid-1930s cast doubt on the theory that a transition had been completed or a "cycle"' terminated. He argued: "Clearly the notion of the demographic transition, despite its fruitfulness as an organizing idea, should not be viewed as inevitable or as a predictive instrument"' (1954: 67-68). And if the transition framework lacked predictive capabilities for Western countries, it was an even less appropriate instrument with which to divine the future of the nonindustrialized world: "The truth is that no country of India's type has ever yet completed the transition. For India, therefore, the demographic transition is an especially poor instrument of prediction"' (1954: 68).

From consideration of transition theory, Davis (1954: 66) moved to a larger question: "Can the various phases of social and economic modernization be deliberately transposed and foreshortened, or must they be viewed as a rigidly fixed sequence of necessary steps?'" He had found wide variability among countries with respect to direction and timing of modernization. He had also found different factors constraining the development of countries differently situated in time and space. Therefore, Davis reasoned that a progression to the modern state need not (indeed, would not) follow a fixed sequence of steps. With respect to India's demographic future, he concluded that "there is no inevitable reason why in India the demographic gap cannot be foreshortened by deliberate policy" (1954: 71; emphasis in original). Unshackling his thinking from the transition framework, Davis began to work fully within the new policy-oriented perspective.

In his assessment of "the possible success of India's fertility control policy," Davis, while never professing complete optimism, presented an impressive catalogue of factors in the Indian situation that made fertility reduction by means of a national family planning program a realistic possibility. A review of the survey research dealing with knowledge and attitudes toward contraception in India led Davis to conclude that, while ignorance of modern contraception prevailed, "there is a preponderantly favorable attitude toward its purpose" (1954: 75). His analysis of the changed conditions of peasant life led him to contend: "In short, the ordinary Indian, with more than the traditional number of children on his hands, with rising ambitions for them, and with conditions of life more difficult, is literally being driven into seeing the necessity of birth control' (1954: 79). Thus by 1954 Davis had become a strong advocate of the direct approach to solving the demographic crisis of the nonindustrialized world. He was arguing forcefully that "India had a chance to 
be the first country to achieve a major revolution in human life-the planned diffusion of fertility control in a peasant population prior to, and for the benefit of, the urban-industrial transition' (1954: 87-88). ${ }^{14}$

In 1945 no one familiar with demographic literature could have foreseen that less than ten years later the principal authors of transition theory would be attempting to lower the birth rates of traditional agrarian societies by providing contraceptives to illiterate peasants. Poor peasants in agrarian societies were the very group that transition theory hypothesized would be the least likely practitioners of contraception. More than a half-century of research on the topic of fertility decline had produced few findings that would support the feasibility of such an endeavor. In Controlled Fertility, a 1940 work of which Notestein was a joint author, this conclusion had been reached:

If the thesis advanced here is valid, the situation will not be rapidly altered by making modern contraception available to populations that have not utilized the folkway methods at their disposal. There must be the will to reduce fertility. If our own history means anything, it means that this comes gradually and in response to broad changes in living conditions. . . . Birth control as an isolated movement-an inexpensive panacea-has small chance for success. (Stix and Notestein, 1940: 150)

Yet, little more than a decade later Notestein spoke of the possibility that the promotion of higher age at marriage and the practice of birth control would considerably reduce the birth rate even in peasant societies (1953: 28).

Why did such a shift in perspective occur? It was because, when the demographic and economic situation of nonindustrialized societies at midcentury was viewed in light of the past experience of already modernized societies, great difficulties were foreseen in contemporary nonindustrialized societies, especially large and densely settled Asian societies, repeating the Western modernization experience. Pessimism on this score led to a conviction that, if comprehensive modernization was to occur, demographic change had to precede industrialization. It led to adoption of a policy orientation with regard to fertility.

The new policy-oriented approach, which viewed fertility as an independent variable that had to be altered, evolved from the older social scientific perspective, which viewed fertility as a dependent variable that reacted to socioeconomic change. But it evolved in a dialectical fashion. The contradictions present in attempting to avert the impending "crisis" within the preexisting social scientific framework generated the new policy orientation and the new development strategy.

\section{The impact of the policy-oriented perspective}

Two immediate tasks faced those who adopted a policy orientation. First, they had to demonstrate the feasibility of the direct approach. Could birth control programs reduce peasant birth rates prior to industrialization? Second, they had to convince policymakers of the advisability of such interventions. 
Demographers pursuing these two tasks were forced to alter the assumptions and "theory" they employed. The analyses they produced differed substantially from those produced under the older social scientific perspective. Looking at these changes in assumptions and theory is one way of clarifying the consequences for the development of US demographic thought that flowed from the shift in perspective. When Notestein and Davis adopted the new policy-oriented approach, they undertook to demonstrate the feasibility and advisability of the direct approach to fertility reduction. The assumptions and theory found in their work of the mid-1950s differed substantially from those in their work of the mid-1940s. An examination of these differences will help identify how demography in the United States was altered by the adoption of the new perspective.

\section{Questions of feasibility}

Could fertility decline be induced in agrarian societies through the provision of contraceptive information and devices to the populace? In assuming an affirmative answer, demographers stepped beyond the boundaries of pure social scientific research. Around this novel contention a certain tension developed within US demographic circles. The social scientific perspective did not assume that access to contraceptives played no role in determining a society's fertility level; it simply suggested that the importance of this factor as a causal agent affecting fertility trends was minor.

Back in 1930 Warren Thompson had argued that contraception was not the "cause" of lowered Western fertility but only the means employed to accomplish that end (1930: 115-116). In 1940 Notestein and Stix were contending that "birth control did not spring suddenly into existence to implement an age-old desire to limit procreation. A strong current of causal sequence ran in the opposite direction. New patterns of living and new values brought growing interest in family limitation that spread the use of known methods and stimulated the development of new ones"' (1940: 150). And Davis's 1948 structural-functional analysis of high fertility as a product of the institutional arrangement of "familistic societies" and low fertility as a product of the institutional arrangement found in "individualistic societies" did not even consider the possibility that ignorance of contraception might be a reason for high fertility (1948: 561-562). He was simply stating that "fertility has always, in every kind of society, been socially controlled" (1948: 556).

This legacy of social scientific research questioned the feasibility of the new policy orientation's solution to high population growth. What made the controversy more intense was the specific population whose fertility these demographers desired to change: poor, peasant, high-fertility peoples. If the policy-oriented approach had adhered closely to the past findings, its target population would have been quite different: urbanites, the middle class, workers in the industrial sector, couples who had already begun to lower their fertility through the use of folk methods. These were the groups, according to the social scientific findings, whose reproductive behavior might be lowered through national family planning programs. 
Of course, in the context of the midcentury's population "crisis," the actual choice of target population was understandable. After all, the highfertility, peasant majorities in nonindustrialized countries were the source of most population growth. If rapid fertility reduction was to occur, it was their reproductive behavior that had to be altered. But, no matter the reason behind the choice, the assumption that provision of contraceptive information and devices to this population would lead to significant reductions in fertility did constitute a slighting of the significance of the structural determinants of reproductive behavior. It was tantamount to assuming that lack of contraceptive knowledge and techniques was a major cause of the current high fertility level of this population. It disregarded much of the accumulated evidence of the past 60 years of research, which had indicated that fertility change was primarily a consequence of socioeconomic change.

How could those like Notestein and Davis who worked within the new policy orientation respond to this legacy of past research, much of it their own, which questioned the feasibility of the new perspective's solution to the current crisis? They could simply ignore it. And much of it was ignored. They could find fault with the most significant product of the social scientific perspective, transition theory. This they also did, even though both men had been formulators of the theory and even though the predictions that the theory had made concerning "high growth potential populations" were coming true.

But more than a critique of transition theory was needed to allay doubts concerning the feasibility of the direct approach. A theoretical justification had to be presented for believing this approach to be possible. Empirical evidence of its feasibility also had to be found.

As we saw earlier, in several of the works Davis published during the mid-1950s $(1953 ; 1955)$ he analyzed how profoundly conditions of the individual peasant's life in India had been altered in the past 30 years. In these works a theoretical justification for optimism about the direct approach can be found. By shifting away from the macro-level analysis common to the social scientific perspective and focusing his attention on the single individual, Davis was able to arrive at the optimistic conclusion that "the ordinary Indian" was "literally being driven into seeing the necessity of birth control" (1954: 79).

In effect Davis had turned on its head transition theory's colonial explanation of the nonindustrialized world's rapid population growth. The changes wrought during the period of colonial domination had all been considered in the colonial explanation: the commercialization and rationalization of agriculture, the increase in agricultural production, the improvement of transportation and communication systems, the decline of famines, the implementation of public health measures, the decline of handicraft industry, the loss of village self-sufficiency, and so on. These formerly had been considered to be changes that presaged a crisis situation-namely, mortality decline unaccompanied by fertility decline. Now Davis argued that these same changes themselves increased the motivation of couples to limit their family size. By shifting from a structural level of analysis to an individual level and by emphasizing the "fundamental" nature of the socioeconomic changes that had 
already occurred rather than simply decrying the paucity of industrial development, Davis was able to find harbingers of hope in "facts" that had formerly bred only despair.

Davis employed the notion of man as an essentially rational being (similar to the classical economists' view of "economic man") in this analysis. High fertility had lost its "utility," and the individual accordingly could be expected to control his reproduction. After all, as both Notestein and Davis observed, the individual peasant was not "stupid."

But why, then, was there little evidence that the villager in India was deliberately controlling his fertility? Davis (1955: 290) supplied an answer: "If he continues to have many children, the chief reason is that he has not yet crystallized his goals in terms of the new settings or found the means of instrumenting new goals." Furnish him with "a redefinition of the situation and with appropriate instrumentalities," Davis argued, and a "considerable" reduction in fertility may result. A government-sponsored family planning program would be an appropriate mechanism for accomplishing this task. Since at that time the Indian government had recently incorporated an appropriate population policy in its First Five-Year Plan and had made provisions for inaugurating a national family planning program, Davis saw good reason to be optimistic about the potential of the direct approach for reducing fertility in India.

By shifting from the macro-level of analysis to the micro-level, Davis was able to generate a theoretical justification of the direct approach. Of course, presuming that the ordinary Indian would actually limit his fertility if provided with "appropriate instrumentalities" entailed deemphasizing the importance of past research on the structural determinants of fertility change. A rather mechanistic view of society had to be assumed. Individuals were considered as isolated atoms who would act "rationally" in their own interest if only given the opportunity. And contentions (1954: 79) that peasants, "with conditions of life becoming more difficult," were "literally being driven into seeing the necessity of birth control" lacked a certain degree of credibility. If poverty bred birth control, why had the poor always been so prolific? More proof of the feasibility of the direct approach was needed: scientific, empirical, "hard" proof if possible.

The aforementioned survey responses of Indian peasant women, indicating two or three children as an appropriate number for a woman aged 40 , suggested to Davis " a desire among Indian peasants for small families." He used these findings to bolster his contention that a national family planning program might lower fertility. The potential utility of such surveys was obvious. If a "ready market" for birth control could be demonstrated, then advocates of the direct approach had hard "scientific"' evidence supporting the feasibility of the approach. Surveys of knowledge, attitudes, and practice with regard to family planning (KAP surveys) became commonplace throughout the $1950 \mathrm{~s}$ and 1960s. By the end of the 1960s, 400 such surveys had been carried out worldwide (Fawcett, 1970: 38). Although criticized (Hauser, 1967: 404) for being "methodologically naive," these surveys generally did collect data that 
could be interpreted to mean that a substantial majority of all respondents were interested in learning how to control their fertility. ${ }^{15}$ The KAP survey supplied to those working within the new policy-oriented perspective their most powerful weapon with which to combat the doubts raised by past research.

Transition demographers had been able to differentiate industrialized, industrializing, and nonindustrialized societies on the basis of the presence and extent of fertility decline. The close relationship between level of economic development and fertility level had been considered confirmation of their contention that fertility trends were consequences of socioeconomic change. Now advocates of the new policy-oriented perspective were able to classify individuals within a given population into users of contraception, potential users, and nonusers. The existence of a sizable group of potential users was considered confirmation of their contention that the direct approach to fertility reduction was feasible.

The KAP surveys not only alleviated demographers' doubts but also proved to be a persuasive instrument for altering the views of important groups concerning the advisability as well as the feasibility of the direct approach. Bernard Berelson (1965: 665-666), for instance, noted this additional attribute of the KAP survey: "As an example, the KAP survey done in Turkey in 1963 was given wide attention and contributed to bringing about the recent change in national population policy. It may even be, contrary to the typical impression of national elites, that there is more political potential in this issue than political risk."

\section{Convincing policymakers}

Once a means of dealing with doubts concerning the feasibility of the direct approach had been developed, demographers were able to marshal some very convincing arguments concerning its advisability. A general tactic adopted by policy-oriented demographers was to analyze present conditions and elaborate pessimistic and optimistic scenarios of the future. By specifying actions capable of influencing the scenario that would unfold, they were able to present a strong case for the advisability of the direct approach.

For instance Notestein, although certainly never a Malthusian predictor of ultimate doom, did describe demographic conditions in Asia as "setting the stage for calamity" and possibly leading to "catastrophes" (1948: 12-13). When discussing densely settled areas in "The population of the world in the year 2000," he presented several "possible" scenarios of the future. One entailed a "period of disorganization"' during which "population growth will be heavily checked by catastrophic losses from time to time and from place to place"' (1950a: 343). He noted that this would come about "only if the world's worst death rates rise spectacularly and hundreds of millions of people die for lack of life's simplest essentials" (1950a: 343). Another entailed "strong and wise indigenous governments" stimulating rapid economic growth. Death rates would fall and populations would grow. There was a "grave danger" even if this optimistic scenario unfolded: "mounting numbers 
will be a major obstacle to sustained improvements in health and living levels unless special measures are taken to speed the reduction of birth rates among masses of the peasant populations"' (1950a: 344).

Notestein expected the actual experience of densely settled societies to vary. "Some catastrophes are probable, and some successful transitions to efficient replacement are possible"' (1950a: 344). By elaborating pessimistic and optimistic scenarios of the future, he set the range within which the future would unfold. By identifying actions capable of affecting the future, he used these scenarios to influence the decisions of policymakers.

Davis followed a similar course of action, but he employed a more negative vision of the probable future. In 1950 he described "the archaic agricultural nations" as being in a "melancholy state" wherein poverty produced population growth, which further entrenched poverty (1950a: 45). He predicted that this vicious circle of poverty and population growth would be broken when "strife and turmoil" reduced "the existing demographic glut" (1950a: 49). Future mortality increase was his expectation; from a "scientific", point of view he thought that the chances of fertility decline occurring "do not appear good"' (1950a: 49).

Davis used his prediction of turmoil and mortality increase as a goad to prod "unwilling" governments to implement birth control programs and attempt a more humane resolution to the crisis (1951: 230-231). In "Future population trends and their significance," Davis even noted that it was the ominous scenario of the future that was behind the "growing body of opinion" favoring efforts to lower fertility prior to industrialization (1953: 17).

As the 1950s progressed, many US demographers and economists working within the new policy-oriented perspective began studies of the "future." These studies sought to demonstrate the negative consequences that would arise from continuation of high fertility levels and the benefits that would accrue from reducing fertility. The use of increasingly sophisticated simulation techniques allowed researchers to quantify in dollars the value of a five-point drop in the birth rate or even of "one birth permanently prevented." The findings of such "futures" research were presented to those making population policy. It was hoped that their policy decisions would be made in light of this evidence. Notestein (1954: 167-168), speaking in 1954 of the well-known Coale and Hoover project (1958), which was then being initiated at Princeton, identified the goal of such "futures"' research:

I am inclined to think that much more progress is likely to be made by the careful construction of numerical models that are based on actual situations, and move out into the future on a wide variety of alternative courses reflecting the conceivable actual developments. We are beginning such a project at Princeton. It will deal in the first instance with a large population characterized by high fertility, high mortality, high density, and very low incomes. We shall endeavor to project the population, by age and sex, into the future in a variety of ways. The object of the projection is not in the least to discover what the future population will be. Instead it is to let us study what the economic consequences of alternative courses of events would be. 
These simulation studies, especially the Coale and Hoover study, had a profound impact. Although not forecasting "disaster" even if current rates of fertility remained unchanged, they demonstrated that improvements in per capita income could be realized if birth rates fell. Although the relative gain associated with even spectacular fertility reduction in the Coale-Hoover model was modest, these modest relative improvements were presented as attainable through low-cost programs, hence offering high rates of return to public investment. The appeal to policymakers was obvious. In large measure the findings of Coale and Hoover and their disciples were responsible for the adoption by rising numbers of nonindustrialized countries of antinatalist policies and birth control programs. These findings also convinced developed countries to fund such efforts.

Most demographers working within the new policy-oriented perspective changed the time orientation of their demographic research. The present and especially the past had been the arenas where demographers working within the older social scientific perspective sought insight in their quest to understand fertility. For most, the past lost its relevance when a policy orientation was adopted. It was judged to hold few lessons capable of aiding those seeking a solution to the current crisis. What was needed was not an understanding of the past, or even of the present, but rather a means by which to influence the future. The molding of the future became all-important; evidence capable of demonstrating the advisability of the direct approäch was of prime importance. "Futures" research, especially simulation studies quantifying the increase in per capita income that would result in $x$ years from lowering the birth rate $y$ amount, served this function eminently well.

There was a major exception to this change in time orientation. In his critical analysis of transition theory, Notestein (1953) pointed to the historical experiences of France and Bulgaria as instances where fertility decline preceded industrialization. Davis (1954), too, commented upon the quite varied "transition" experiences of European societies. Beginning in the 1950s a number of US demographers became interested in examining the historical evidence, desirous of testing assertions such as those found in transition theory. The question that most attracted their attention was specifying the causes of fertility decline, particularly European fertility decline. Given the goal of policyoriented demographers at the time, this historical question had great contemporary relevance.

The perspective of historical demographers was strictly social scientific: attempting to specify the determinants of past demographic trends. Yet the conclusions arising from their examination of European subnational units raised doubts concerning the broad generalizations found in early formulations of transition theory. ${ }^{16}$ A research group under the direction of Ansley Coale examined the relationship between the timing of marital fertility decline in a number of European countries and the levels of industrialization, urbanization, literacy, and infant mortality. By 1969 Coale was reporting:

The range of each index is broad, so that there appears to be little in the statistical record for Europe which confirms the existence of an association between the 
beginning of fertility decline and any specific level, or threshold, of economic and social development. (1969: 18)

Thus, interestingly, during the period when most demographers were adopting a policy orientation focused on molding the future, some were stimulated to undertake historical, social scientific research-research that caused all to lower their voices when speaking of requisite structural changes needed to precipitate fertility decline.

\section{Past,_present, and future}

During the 1950s the assumptions and theories employed by demographers in the United States, as well as the kind of analyses produced by them, were affected by the shift from social scientific to policy perspective. This shift had a profound impact on US demography. The nature of this impact can best be summarized by contrasting the central features of the older social scientific perspective toward fertility with those of the new policy-oriented one. Such a contrast can also be used to speculate about what changes might be associated with a current change in orientation.

Within the older social scientific perspective the demographer was an investigator, a detached observer of past and present social, economic, and demographic trends. He sought an understanding of the underlying causes of fertility change. His vision was historical because he assumed that present conditions were the result of broad historical forces at work. He employed a high level of abstraction in his analysis as he attempted to specify the nature of these forces. He freely used such abstract concepts as "Western civilization," the "modernization process," "colonialism," and the like. As a result the theories he produced, such as transition theory, possessed a high level of generalizability since they related fertility change to the workings of broad historical forces.

He assumed that society was a highly integrated and cohesive system. He sought to understand a particular behavior pattern such as high or low reproduction by relating it to structural features of the social system in which it occurred. Change in behavior took place as individuals reacted to structural changes in the social system. In short, he was a detached investigator, prone to macro-level analysis, who considered structural features to be the prime determinants of individual behavior.

Within the new policy-oriented perspective, the demographer was an advocate, a proponent of change. His vision was ahistorical, focused on the future. Because he was concerned with producing a specific change, he desired a "nuts and bolts" knowledge of how things worked. Accordingly he employed a low level of abstraction in his analysis as he sought to specify what particular actions had to be taken to produce the desired change.

He assumed that society was basically a multiplicity of individuals rather loosely stranded together. He sought to understand a particular behavior such as high or low reproduction by asking what utility it might have for the 
individual. He believed that behavior changed when its utility for the individual changed. Working with this atomistic vision of society, he assumed that when individuals acted in a "nonutilitarian" manner, they did so because of ignorance or because they lacked the means to do otherwise. He therefore called for education and programs aimed at providing individuals with the means of achieving new goals. He was also an interventionist who sought to alter what he considered to be destructive behavior by implementing specific changes that would alter the utility of that behavior for the individual. In short, he was an advocate, prone to micro-level analysis, who considered behavior to be primarily determined by utilitarian considerations of the individual.

The changes occurring in US demography between 1945 and 1955 shed special light on the tensions existing within demography due to its dual nature as social science and policy science. During the 1950 s, from a social scientific viewpoint, there was little need to develop a new demographic perspective to deal with the population dynamics of the postwar nonindustrialized world. Transition theory had predicted the trends occurring. They were "understood"; their determinants could be specified. Yet a new perspective on fertility was adopted, and by a generation of demographers closely associated with the social scientific tradition. The policy orientation arose not out of a need for greater "understanding" of demographic trends, but out of a desire to alter those trends since they threatened to generate harmful effects.

Although adoption by most US demographers of a policy orientation marked a break with the past, this break was not complete. The majority of policy-oriented demographers still believed that structural changes associated with the modernization process had been the prime determinants of past demographic changes, that these changes had followed the general pattern described by transition theory, and that contemporary nonindustrialized societies would have undergone a "normal" demographic transition if they had also undergone a Western modernization experience. The break resulted from the novel contention of policy-oriented demographers that fertility decline could be directly induced in agrarian societies. The older perspective did not die out-in fact the work of historical demographers added much to the understanding of past trends. It simply was not used by policy-oriented demographers in their analysis of contemporary population dynamics.

With two perspectives coexisting within the field, the years from 1955 to the early 1970 s were marked by controversy and debate. Not all US demographers had adopted a policy orientation; some early advocates later changed their position. Although answers to questions concerning the feasibility of the direct approach had been elaborated in the 1950s, these answers were not definitive. Doubts continued to surround this topic. These doubts would disappear only if the birth rate of an agrarian society declined in response to policy interventions. During the 1960s Taiwan, South Korea, Hong Kong, Singapore, Malaysia, and Ceylon experienced noticeable fertility declines, established national family planning programs, and underwent significant economic development. But this concurrence of events allowed both advocates and critics of the direct approach to draw quite different conclusions from the 
same "facts." Such trends served to fuel the debate between "developmentalists" and "family planners.", 17

But over the last decade the gap between these two groups has lessened considerably. A number of factors have contributed to this. From 1960 to 1980 developing nations have experienced nontrivial growth in their per capita gross national product. Agricultural production has also outpaced population growth. Fears that rapid population growth might lead to economic stagnation and food shortages, which had motivated many demographers during the 1950 s to adopt a policy orientation, have lessened. The findings of historical demographers concerning the lack of past association between fertility decline and any specific level of economic development have muted the voices of those who formerly contended that certain structural changes were needed before birth rates would decline. Finally, birth rates have declined in a significant number of developing societies-at different levels of industrial development, in different geographic regions, and with different cultural heritages. As this trend increases in pace, magnitude, and extent, the focal point of controversy diminishes.

At present, the policy and social scientific components of demography can coexist harmoniously. Widespread fertility decline has become a trend that all demographers seek to understand. Why does it occur in certain places at certain times? What role do social, economic, political, cultural, and policy factors play in either inhibiting or facilitating it? Such questions involve attempting to understand an ongoing demographic trend, an essential social scientific endeavor. This knowledge, though, can also be used to construct better blueprints for action; it has great policy utility. As the goal of understanding contemporary fertility decline rises high on the agenda of the discipline, demographers can simultaneously be good social scientists and effective policy scientists.

If such an agenda remains in place long, however, the distinctive traits of the policy orientation as developed in the 1950s are likely to disappear. Identifying the determinants of contemporary fertility decline calls for comparative and historical analysis. It calls for identifying the forces at work behind the trend and working at a high level of abstraction. Abstract concepts capable of encapsulating the nature of these forces are needed to understand the pace, magnitude, and spread of fertility decline, to find patterns in its temporal and spatial appearance. In the future, therefore, most demographers are likely to be working again within a social scientific perspective. At least until another "crisis", makes its appearance.

\section{Notes}

1 Philip Hauser offered this description of the tension: "I think whenever we deal with 'the population problem' the demographer becomes schizophrenic. That part of him which is essentially the scientist becomes completely confused with that part of him which cries out for social engineering"' (1954: 187).
2 In 1903 Frederick Bushee presented Dumont's ideas to the American audience (1903: 355-361).

3 Fetter's work is especially interesting on this point since he offers a separate analysis of the factors affecting the reproductive behavior of each particular social class (1915: 
416). The wealthy had a strong motivation to preserve the status of their children, which they could most easily do by limiting the number of their offspring. "It is a simple division: wealth the dividend, number of children the divisor." The poor derived their income from wages. Where not restricted by child-labor laws, children at an early age could begin to contribute to their parents' income. Because the poor had no savings, in later life the child's income would be determined by the general level of wages and not by the number of his siblings. Therefore, poor parents did not have the same motivation to limit their offspring. It was among the middle class that the greatest control over fertility was exercised. They were striving to achieve higher status for themselves and their offspring. They desired to give their children every advantage. Since their means were limited, their desire to increase per-child expenditure induced them to curb their fertility.

4 See the earlier work of Kuczynski for a very detailed treatment of this point (1928, 1931). His analysis of the fertility trends of Eastern and Southern European societies showed that fertility had decreased, but at a later time period and to a lesser extent than in the rest of Europe (1931: 61-64). Conditions in Central Europe, he noted, were "in a transitional stage" (1931: 62). I believe this was the first time the word "transitional" was used to describe a shift in demographic patterns to a more Western European model.

5 For example, see Wilbert Moore's elaboration (1945: 141-142) of how the process of "secularization" ("that is, the breaking down of particularistic ties and the affiliation of the individual with larger and more specialized groups') induced fertility decline.

6 Ross (1909: 37) observed that "where a backward folk is brought under efficient modern administration, the proportion of deaths may be rapidly reduced even though the people continue to breed in the old reckless way." In the same passage he also specified the different sets of changes affecting levels of mortality and fertility.

7 Examination of the original elaborations of transition theory by Kirk (1944), Notestein (1945), Davis (1945), and Thompson (1944) shows that the level of fertility, not the extent of population growth, was the criterion used to place a population in one of the three stages of demographic evolution. Frank Notestein was particularly emphatic about this point. In "Population of the world in the year 2000," he contended that "the essential characteristic" of regions of transitional growth "is that even the birth rates, which respond much more slowly than the death rates to changes in the social setting, have a well-established downward trend" (1950a: 340). He was also quite explicit about the use of a fertility criterion, not a population growth criterion, to define "regions of high growth potential": "The third of our population types is that of high growth potential. It is the least homogeneous of all, having as its only essential characteristic the fact that the birth rates have thus far given no clear indication of a downward trend" (1950a: 341).

8 The Committee on the Study of Social and Psychological Factors Affecting Fertility had been working during the 1940s. The major fruit of their labor, The Indianapolis Study, was the first example of a research approach that, it was hoped, could produce an explanation for the postwar "baby boom."

9 Notestein was president of the Population Council from 1959 to 1968 . Examination of the "Report of the President" contained in the Annual Report of the Population Council (New York: The Population Council) for those years documents Notestein's confidence in the efficacy of the direct approach. His thoughts on this point are summarized in a 1967 article, "The population crisis: Reasons for hope."

10 Davis and Blake, at a later date (1956), developed their elaborate framework for analyzing the relationship between social structure and fertility. This framework specified 11 "intermediate variables," all of which theoretically could be manipulated to achieve a reduction in fertility.

11 This was an interesting conclusion for Davis to draw from the data. The detailed analysis of fertility differentials to which Davis referred in this 1950 article was contained in his 1946 work, "Human fertility in India." The latter analysis led him to conclude that "no downward trend is imminent" in Indian birth rates. The "certain highly placed groups" whose fertility was declining, to which Davis referred in this 1950 article, were the Parsi. The Parsi are a distinctive religious group, which composed 0.032 percent of the Indian population in 1941 (Davis 1951: 185). 
12 Economic Growth: Brazil, India, Japan, edited by Simon Kuznets, Wilbert Moore, and Joseph Spengler, was a compilation of papers originally given during the Spring of 1952. The authors were then given "over a year" to revise their papers. The volume was published in 1955.

13 Davis was arguing that a decline in mortality was producing a new phenomenon with which all couples had to deal: an increase in family size due to children surviving. The added physical and financial burdens imposed on parents by having more of their conceptions result in surviving children were considered to be increasing their motivation for birth control. This theory was first put forward by Penrose (1934: 115-120) in his analysis of Japanese demographic trends. Davis was the only US formulator of transition theory to incorporate this contention into his version of the theory (1945: 5). In "The theory of change and response in modern demographic history," he later argued (1963: 352) that this enlargement of the family historically had been the stimulus that elicited a whole range of demographic responses from couples experiencing it. During the development of social scientific explanations of Western fertility decline in the first half of the twentieth century, few US demographers considered the change wrought by mortality decline as a prime cause of fertility decline. Rather, they distinguished the subsets of changes associated with the Industrial Revolution that had an impact upon mortality and fertility. With the adoption of a policy orientation in the 1950s, the mortality decline argument gained wide acceptance. It offered reason to hope that, with declining death rates, couples in nonindustrialized societies would be motivated to limit fertility. It was controversial because no one knew whether mortality decline alone would generate sufficient motivation to induce fertility decline. In the past mortality decline had been associated with general economic improvement and much structural change. In conditions of economic stagnation, the mortality decline argument devolved into a poverty argument.

14 This description of Davis's 1954 position on fertility control and "planned parenthood" programs might be surprising to readers familiar only with his 1967 critique of family planning programs ("Population policy: Will current programs succeed?'). His
1967 position differs significantly from his earlier position in major ways. In 1967 Davis considered the indirect approach to fertility control to be of paramount importance since it attempted to alter the motivation to have children: "If it were admitted that the creation and care of new human beings is socially motivated, like other forms of behavior, by being part of a system of rewards and punishments that is built into human relationships, and thus is bound up with the individual's economic and personal interests, it would be apparent that the social structure and economy must be changed before a deliberate reduction in the birth rate can be achieved" (1967: 733). This quote implies that in 1967 Davis no longer considered the socioeconomic changes that had already taken place in agrarian societies to have been so great that the "ordinary Indian" is "literally being driven into seeing the necessity of birth control." Having altered his position on this point, he was led to question whether family planning programs, with an ideology that each couple had a "right" to determine their own family size, would ever produce the low birth rates needed from a societal point of view. He was distinguishing between population control and family planning programs. In the mid-1950s Davis made no such distinction. At that time he explicitly mentioned the need for population control and explicitly mentioned "planned parenthood" programs as a means of accomplishing that end.

15 For an article that contains many references to works criticizing the methodology of KAP surveys, see Marino (1971).

16 For a treatment that examines the original statements of transition theory in light of the findings of historical demographers, see Coale (1973).

17 The controversy surrounding the direct approach did not lower interest in it or slow its growth. From its inception in the early 1950s monetary support from a variety of sources had been available for its propagation. Large numbers of professionals from public health and other backgrounds quite remote from demography had been enlisted to aid in the effort. This approach, then, had become well institutionalized and had assumed dimensions beyond the boundaries of demography as conventionally defined. 


\section{References}

Berelson, Bernard. 1965. "KAP studies on fertility," in Family Planning and Population Programs, ed. Bernard Berelson et al. Chicago: University of Chicago Press.

Billings, John. 1893. "The diminished birth-rate in the United States." The Forum 15, no. 4 (June): $467-477$.

Bowen, Ezra. 1931. An Hypothesis of Population Growth. New York: Columbia University Press.

Bushee, Frederick. 1903. "The declining birth-rate and its cause." Popular Science Monthly 63, no. 19 (August): 355-361.

Carver, Thomas. 1904. The Distribution of Wealth. New York: Macmillan.

Clark, John Bates. 1907. Essentials of Economic Theory. New York: Macmillan.

Coale, Ansley. 1969. "The decline of fertility in Europe from the French Revolution to World War II,' in Fertility and Family Planning, ed. S. J. Behrman et al. Ann Arbor: University of Michigan Press.

—. 1973. 'Transition theory,"' in International Population Conference, Vol. 2. Liège: International Union for the Scientific Study of Population.

- and Edgar Hoover. 1958. Population Growth and Economic Development in Low-Income Countries. Princeton: Princeton University Press.

Crocker, W. R. 1931. The Japanese Population Problem. London: George Allen and Unwin Ltd.

Davis, Kingsley. 1944. "Demographic fact and policy in India," in Demographic Studies of Selected Areas of Rapid Growth. New York: Milbank Memorial Fund.

- 1945. "The world demographic transition." The Annals of the American Academy of Political and Social Sciences 237 (January): 1-11.

- 1946. "Human fertility in India."' American Journal of Sociology 52, no.

3 (November): 243-254.

1948. Human Society. New York: Macmillan.

. 1950a. "Population and change in backward areas." Columbia Journal of

International Affairs 4, no. 2 (Spring): 41-51.

1950b. "Population and the further spread of industrial society." Proceedings

of the American Philosophical Society 95, no. 1 (February): 8-19.

- 1951. The Population of India and Pakistan. Princeton: Princeton University Press.

- 1953. "Future population trends and their significance." Transactions of the Eighteenth North American Wildlife Conference. Washington, D.C.: Wildlife Management Institute.

- 1954. "Fertility control and the demographic transition in India," in The Interrelations of Demographic, Economic, and Social Problems in Selected Underdeveloped Areas. New York: Milbank Memorial Fund.

- 1955. "Social and demographic aspects of economic development," in Economic Growth: Brazil, India, Japan, ed. Simon Kuznets, Wilbert E. Moore, and Joseph J. Spengler. North Carolina: Duke University Press.

. 1963. "The theory of change and response in modern demographic history," Population Index 29: 345-364.

- 1967. "Population policy: Will current programs succeed?," Science 158, no. 3802 (November): 730-739.

, and Judith Blake. 1956. "Social structure and fertility: An analytic framework," Economic Development and Cultural Change 4, no. 3 (April): 211-235.

Dumont, Arsène. 1890. Dépopulation et Civilisation., Paris: Schleicher Frères. 
Ely, Richard. 1893. Outlines of Economics. New York: Macmillan.

Emerick, Charles. 1911. "Is the diminishing birth-rate volitional?," The Popular Science Monthly 78, no. 1 (January): 71-80.

Fawcett, James. 1970. Psychology and Population. New York: The Population Council.

Fetter, Frank. 1915. Economic Principles. New York: The Century Co.

Giddings, Franklin. 1898. The Elements of Sociology. New York: Macmillan.

Hauser, Philip. 1954. "Research needs and suggested projects,"' in The Interrelations of Demographic, Economic, and Social Problems in Selected Underdeveloped Areas. New York: Milbank Memorial Fund.

- 1967. "Family planning and population programs: A book review article." Demography 4, no. 1 (February): 397-414.

Hoffman, Federick. 1914. "The significance of a declining death rate." Address delivered before the National Conference on Race Betterment, Battle Creek, Michigan (January). New Jersey: Prudential Insurance Co.

Holland, W. L. 1936. "Population problems and policies in the Far East." The Annals of the American Academy of Political and Social Sciences 188: 307-318.

Keller, Albert. 1917. "'Birth control." Yale Review 7, no. 1 (October): 129-139.

Kirk, Dudley. 1944. "Population changes and the postwar world." American Sociological Review 9, no. 1 (February): 28-35.

Kuczynski, Robert. 1928. The Balance of Births and Deaths, Vol. 1: Western and Northern Europe. New York: Macmillan.

. 1931. The Balance of Births and Deaths, Vol. 2: Eastern and Southern Europe. Washington, D.C.: The Brookings Institution.

MacIver, Robert. 1926. "Trend of population with respect to a future equilibrium," in Population Problems, ed. Louis Dublin. New York: Houghton Mifflin.

Mannheim, Karl. 1936. Ideology and Utopia. New York: Harcourt, Brace and World. Marino, Anthony. 1971. "KAP surveys and the politics of family planning." Concerned Demography 3, no. 1 (Fall): 36-75.

Moore, Wilbert. 1945. Economic Demography of Eastern and Southern Europe. Geneva: League of Nations.

Notestein, Frank W. 1943. "Some implications of population change for post-war Europe." Proceedings of the American Philosophical Society 87, no. 2 (August): $165-174$.

1944. "Problems of policy in relation to areas of heavy population pressure," in Demographic Studies of Selected Areas of Rapid Growth. New York: Milbank Memorial Fund.

- 1945. "Population-the long view,"' in Food for the World, ed. Theodore Schultz. Chicago: University of Chicago Press.

- 1948. "Summary of the demographic background of problems of underdeveloped areas," in International Approaches to Problems of Underdeveloped Areas. New York: Milbank Memorial Fund.

. 1950a. "The population of the world in the year 2000." American Statistical Association Journal 45 (September): 335-345.

- 1950b. "The reduction of human fertility as an aid to programs of economic development in densely settled agrarian regions," in Modernization Programs in Relation to Human Resources and Population Problems. New York: Milbank Memorial Fund.

- 1953. "Economic problems of population change." Address delivered before the Eighth International Conference of Agricultural Economists. In Proceedings 
of the Eighth International Conference of Agricultural Economists. New York: Oxford University Press.

1954. “'Discussion,' in Interrelations of Demographic, Economic, and Social Problems in Selected Underdeveloped Areas. New York: Milbank Memorial Fund.

. 1967. "The population crisis: Reasons for hope." Foreign Affairs 46, no.

1 (October): 167-180.

Penrose, E. F. 1934. Population Theories and Their Application with Special Reference to Japan. California: Food Research Institute, Stanford University.

. 1940. "Mortality, reproduction, and the rate of increase of the population since 1920," in The Industrialization of Japan and Manchukuo, 1930-1940, ed.

E. B. Schumpeter. New York: Macmillan.

Reuter, Edward. 1923. Population Problems. Philadelphia: J. B. Lippincott.

Ross, Edward. 1907. "Western civilization and the birth-rate." American Journal of Sociology 12, no. 5 (March): 607-632.

-1909. Changing America. New York: Chautaugua Press.

- 1927. Standing Room Only? New York: The Century Co.

Rossiter, William. 1911. "The pressure of population.' The Atlantic Monthly 108, no. 6 (December): $836-843$.

- 1923. "The adventure of population growth." Journal of the American Statistical Association 18, no. 141 (March): 561-574.

Stix, Regine, and Frank Notestein. 1940. Controlled Fertility. Baltimore: Williams and Wilkins.

Sumner, William Graham. 1885. Problems in Political Economy. New York: Henry Holt and Co.

- and Albert Keller. 1927. The Science of Society, Vol. 1. New Haven: Yale University Press.

Taeuber, Irene, and Edwin Beal. 1944. "The dynamics of population in Japan," in Demographic Studies of Selected Areas of Rapid Growth. New York: Milbank Memorial Fund.

Taussig, F. W. 1911. Principles of Economics, Vol. 2. New York: Macmillan.

Thompson, Warren. 1929. "Population." American Journal of Sociology 34, no. 6 (May): 959-975.

1930. Population Problems. New York: McGraw-Hill.

- 1944. Plenty of People. Pennsylvania: The Jacques Cattell Press.

. 1946. Population and Peace in the Pacific. Chicago: University of Chicago Press.

Tucker, George. 1843. The Progress of the United States in Population and Wealth in Fifty Years. Boston: Little and Brown.

Uyeda, Teijiro. 1933. "The future of the Japanese population." Pacific Affairs 6, no. 6 (June-July): 297-304.

Vance, Rupert. 1952. "Is theory for demographers?" Social Forces 31, no. 1 (October): 9-13.

Walker, Francis. 1899. Discussions in Economics and Statistics, Vol. 2. New York: Henry Holt and Co.

Willcox, Walter. 1906. "The expansion of Europe and its influence upon population," in Studies in Philosophy and Psychology. New York: Houghton, Mifflin and Co. - 1916. "The nature and significance of the changes in the birth and death rates in recent years." Publications of the American Statistical Association 15, no. 113 (March): 1-15. 